\title{
Non-accidental structural chromosome aberrations in established monkey B-lymphocyte cell lines
}

\section{Daredzhan Araviashvili*,}

Olga Chzhu,

Igor Marinich,

\section{Irina Danilova}

FSBSI Research Institute of Medical Primatology,

177 Mira St., Veseloe, Adler region, Sochi 354376, Krasnodar krai, Russia
Established primate lymphocyte cell lines obtained from tumour samples and from EBV-positive monkeys served us as the model system for studying the role of genetic factors and chromosomal abnormalities in malignization. The investigation of chromosome regions and genes involved in chromosomal aberrations leading to malignization in these lines was the aim of our work. Cytogenetic analysis was performed at different stages of cultivation in vitro. To determine the oncogenes and tumour suppressor genes located on aberrant chromosomes, data on mapping rhesus macaque genes, and high similarity of human and monkey karyotypes were used. We found that, in the line obtained from lymphomatous baboon tissue, the inactivation of tumour suppressor gene RB1 on chromosome 17 after chromosomal rearrangement is one of the most probable causes of in vivo malignization. Chromosomal aberrations at the region of oncogene c-Ki-ras and tumour suppressor gene TP53 change the proliferative status and differentiation in established cell lines obtained from healthy but EBV-seropositive primates. The other cause of malignization in these lines is an increase in expression of the oncogene c-myc caused by trisomy of chromosome 8 where c-myc is located. Structural aberrations in established primate cell lines affecting several chromosomal loci were identified as: (1) causing the proto-oncogene activation - the central event in the tumour clone occurrence, and (2) deactivating tumour suppressor genes. The change in the chromosome number leads to increase in oncogenic products and to damage of regulatory functions associated with cell proliferation.

Keywords: cytogenetic analysis, karyotype, chromosome rearrangement, gene localization

\footnotetext{
*Corresponding author. Email: dar.arav@yandex.ru
} 


\section{INTRODUCTION}

The incidence of lymphoma increased at the end of the twentieth century. People of various ages suffer from this type of cancer. Their favourable prognoses depend on clinical and immunomorphological features of lymphoma (PevelingOberhag et al., 2013).

Infection with the Epstein-Barr virus (EBV) greatly increases the risk of lymphoma. The Epstein-Barr virus is a human herpesvirus 4 , which targets B-lymphocytes and causes infectious mononucleosis in humans (Shannon-Lowe et al., 2017). After that, individuals become asymptomatic EBV carriers. The exact mechanism of EBV cancer induction is still unknown, though increased titers of EBV antibodies, high content of viral DNA in blood plasma of patients, and monoclonality of viral genome in giant ReedSternberg cells in Hodgkin's lymphoma shows the role of the virus in tumour development (Gurtsevitch et al., 2018). It was found, that in Burkitt lymphoma, which is non-Hodgkin's one, the viral protein Epstein-Barr nuclear antigen 1 (EBNA1) is expressed; proteins EBNA-1, LMP1 , and LMP-2 are expressed in diffuse large Bcell lymphoma, in NK/T cell lymphoma, and Hodgkin's lymphoma; nine EBV proteins are expressed in patients with heavy immunodeficiency (after organ transplantation or HIV infection) (Shannon-Lowe et al., 2017).

Lymphoma is characterized by enlargement of lymph nodes that accumulate malignant lymphocytes. By present time, the genes influencing on tumour development were described. They are known as proto-oncogenes and tumour suppressor genes. In normal cell, protooncogenes do not promote tumour growth, but under some influences these genes become oncogenic. The direct increase in gene expression causes uncontrolled levels of active protein in a cell, or the protein structure change makes the protein active and stable to degradation. In the presence of active oncogene, the cell does not undergo apoptosis; it grows and becomes malignant (Mugnaini, Ghosh, 2016).

Chromosomal translocations detected in lymphomas result in the transfer of proto-on- cogene to the loci of immunoglobulin genes. It leads to permanently increased expression of the proto-oncogene. In acute leukaemia, translocations usually cause the merge of two genes and appearance of chimeric protein with oncogenic properties (Jung et al., 2006).

During the maturation of B-lymphocytes, many DNA rearrangements occur in their genome. Even in lymphocytes of healthy people, the oncogenic translocations in immunoglobulin loci were found. For example, in $50-60 \%$ of healthy adults, the translocation $b c l 2 / \mathrm{IgH}$ was registered, and in $2 \%$ - the translocation $c-m y c / \mathrm{IgH}$. The proto-oncogene product $\mathrm{Bcl} 2$ suppresses the apoptosis, and the protein Myc is a transcriptional factor regulating expression of $15 \%$ genes (Levy et al., 2017).

RAS (Retrovirus Associated DNA Sequences) is a family of other important genes. Proteins Ras are small GTPases possessing similar three-dimensional structure. When Ras proteins are bound to GTP before hydrolysis, they activate mitogen-activated protein kinase cascade causing cell growth and division. Ras mutations causing the loss of GTPase activity result in over-activation of cell growth and decrease of apoptosis that are favourable conditions for cancer. According to literature, Ras mutations were detected in $25 \%$ of human tumours (Gorfe, Cho, 2019).

In healthy cells, the growth is also controlled by tumour suppressor proteins. For example, the protein $\mathrm{Rb}$ prevents progression from $\mathrm{G} 1$ to $\mathrm{S}$ phase of the cell cycle. Rb binds transcriptional factors E2F and inhibits transcription of some cyclins and proteins necessary for DNA replication. However, if the $\mathrm{Rb}$ protein is phosphorylated or mutated, $\mathrm{Rb}$ loses inhibiting functions because the complex Rb-E2F dissociates (Uxa et al., 2019). The cyclins controlled by the mitogen-activated protein kinase cascade are responsible for $\mathrm{Rb}$ phosphorylation. Under normal conditions, $\mathrm{Rb}$ protein is phosphorylated in S, G2, and $\mathrm{M}$ phases. Then PP1 protein dephosphorylates $\mathrm{Rb}$ at $\mathrm{M} / \mathrm{G} 1$ transition and $\mathrm{Rb}$ becomes the cell growth inhibitor again. The $R B$ gene can be damaged or inactivated by mutations 
or chromosomal rearrangements, and the cell uncontrollably goes to the $S$ phase and through the cycle. The deletion of $R B$ significantly increases the probability of cancer due to aneuploidy appearance (Di Fiore et al., 2013).

The other tumour suppressor is protein p53, which stops G1/S transition if DNA damage is present and initiates transcription of DNA repair proteins or apoptosis in the case of irreparable DNA damage (Draganov et al., 2019). Also, protein p53 prevents the formation of new blood vessels in a tumour. In normal cells, protein p53 binds to other protein Mdm2. Mdm2 marks p53 with ubiquitin and then p53 is degraded by the proteasome. In response to stress signals, ubiquitin is removed from p53 by the specific protease and p53 is not degraded. Mitogen-activated protein kinases phosphorylate the $\mathrm{N}$-terminal end of p53, this prevents $\mathrm{Mdm} 2$ binding. According to the literature, in $50 \%$ of tumours, the TP53 gene is mutated or inactivated (Aberg et al., 2017).

Determining proto-oncogenes located on aberrant chromosomes at lymphomas and leukaemias is of great importance in elucidating the role of specific chromosomal aberrations in malignization. According to PubMed database, there is no literature on chromosomal aberrations in monkey tumours and some translocations in human B-cell neoplasms are described. As we have already mentioned, these are translocations of $c-m y c$ or $b c l$ genes $(b c l-2, b c l-6)$ to loci of immunoglobulin genes coding heavy or light (kappa, lambda) chains, or translocations of immunoglobulin genes to the proximity of $c-m y c$ or $b c l$ (Bende, 2007). C-myc is located on chromosome $8, b c l-2$ - on chromosome $18, b c l-6$ - on chromosome 3, Ig heavy chain - on chromosome 14, Ig kappa - on chromosome 2, and Ig lambda - on chromosome 22. Translocations $\mathrm{t}(8 ; 14), \mathrm{t}(3 ; 14), \mathrm{t}(8 ; 22)$ and $\mathrm{t}(14 ; 18), \mathrm{t}(2 ; 8)$ were found in human B-cell lymphomas. Also, the translocation of cyclin D1 gene $t(11 ; 14)$ and the translocation of pax5 gene coding the protein important for B-cell differentiation $t(9 ; 14)$ were registered (Bende et al., 2007).
For studying the role of genetic factors and chromosomal abnormalities in the occurrence, development, and malignant progression of haemoblastosis, primate lymphocyte cell lines are used as the model system. We obtained a number of our established Blymphocyte suspension lines in the process of hemopoietic tissue cultivation, using material from hamadryas baboon suffering from lymphoma and EBV-positive bear macaques (Araviashvili et al., 1994). We suggested that chromosomal rearrangements in these lines affected the genes involved in cell growth regulation.

By the present time, genomes of some monkeys (rhesus macaque, olive baboon, etc.) and humans are sequenced (Ensembl, 2019). Average human-macaque sequence identity is approximately $93 \%$ (Gibbs et al., 2007). The discovered regions of oncogene and tumour suppressor gene location (without precise localisation) in monkey chromosomes allowed us to identify the genes involved in chromosomal aberrations specific for the established lymphocyte cell lines.

With our work, we aimed to investigate the molecular reasons for primate lymphocyte cell malignization after some structural chromosomal rearrangements. This is new for monkey lines, the aberrations in which have not been investigated before; the comparison with data already obtained for humans is also interesting.

\section{MATERIALS AND METHODS}

Cell culture. Cell lines were cultivated in the nutritional medium RPMI-1640 containing $15 \%$ foetal bovine serum, L-glutamine $300 \mu \mathrm{g} / \mathrm{ml}$. penicillin $100 \mu \mathrm{g} / \mathrm{ml}$ and streptomycin $50 \mu \mathrm{g} / \mathrm{ml}$. The cultured lines were established B-cell suspension lines LUG-4 and its subclones E1-1, E5-1 and E9-1 obtained from baboon ill with haemoblastosis and lines MAL-1, MB-20 obtained from clinically healthy bear macaques (Macaca arctoides) seropositive against EBV-like virus, after cell stimulation with phytohemagglutinin (PHA). 
Cytogenetic analysis. Cell cultures at the stage of logarithmic growth, i.e., 2-3 days after seeding in RPMI-1640 medium, without the addition of colchicine were used to obtain slides with metaphase plates. Cell suspensions were transferred into centrifuge tubes $(5 \mathrm{ml}$ per tube), then centrifuged for $5 \mathrm{~min}$ at $1000 \mathrm{rpm}$. After centrifugation, the most of supernatant was removed, with approximately $1-2 \mathrm{ml}$ of supernatant left in a tube.

The cells were hypotonised in $0.56 \% \mathrm{KCl}$ solution or its mixture with $1 \%$ sodium citrate (1:1). The volume of hypotonic solution used was $6 \mathrm{ml}$. Then the cells were incubated for $10 \mathrm{~min}$ at $37^{\circ} \mathrm{C}$. The fixating mixture contained methanol and acetic acid in proportion 3:1. Two drops of the fixating mixture were added to hypotonised cells and then centrifuged for $5 \mathrm{~min}$ at $1000 \mathrm{rpm}$. After removal of the supernatant, the residue was resuspended and $5 \mathrm{ml}$ of fresh cold fixating mixture was carefully added by dropping. Each fixation lasted for 1 hour. The fixating mixture was changed three times. The end volume of the fixating mixture depended on the number of cells and was equal to 2-3 ml. After that, the suspension of fixed cells was dropped on cold wet slides and then dried.

Staining. To determine the number of chromosomes, metaphase plates with remaining cytoplasm were stained by $1 \%$ Giemsa solution in phosphate buffer $(\mathrm{pH}=6.8)$ for 5-6 min. Then 100 metaphase plates with remaining cytoplasm, moderate coiling of chromosomes and non-overlapping chromosomes were analysed. The percentage of the cells with modal chro- mosome number was found at analysis of 100 metaphase plates. The percentage of polyploidy cells was found during the analysis of 1000 metaphase plates from 3-4 slides.

For a detailed investigation of karyotypes, the chromosome G-banding method was used for differential staining. Unstained slides containing a large number of metaphase plates without cytoplasm and with good morphology and non-overlapping chromosomes were thermostated for $8-12$ hours at $60^{\circ} \mathrm{C}$. Then the slides were incubated for 1-5 $\mathrm{min}$ at the room temperature in $0.011 \%$ Trypsin solution, in which the solvent was $0.01 \%$ Versene solution, and Dglucose $0.4 \mathrm{mg} / \mathrm{ml}$, KCL $0.17 \mathrm{mg} / \mathrm{ml}$ and $\mathrm{NaCl}$ $1.7 \mathrm{mg} / \mathrm{ml}$ were added. After that, the slides were washed for $15 \mathrm{~s}$ in the water mixture of D-glucose $1 \mathrm{mg} / \mathrm{ml}$, KCL $0.4 \mathrm{mg} / \mathrm{ml}$, and $\mathrm{NaCl}$ $8 \mathrm{mg} / \mathrm{ml}$. The slides were stained in $2 \%$ Giemsa solved in phosphate buffer $(\mathrm{pH}=6.8)$ for 5-6 min.

Search in the Ensembl database. To determine the localisation of oncogenes and tumour suppressor genes on chromosomes of the Old World monkeys, data on mapping macaque and baboon genes and high similarity of human and monkey karyotypes were used (Ensembl, 2019; Gibbs et al., 2007; Wienberg et al., 1992).

\section{RESULTS}

Six established primate B-lymphocyte cultures were investigated. Data of cytogenetic analysis are presented in Table 1 and Figs. 1-3.

Table 1. Characterization of monkey lymphocyte cell line karyotypes

\begin{tabular}{|c|c|c|c|c|}
\hline Cell line & Diagnosis & Passage & Karyotype & $\begin{array}{c}\text { Chromosomal rearrange- } \\
\text { ments/localisation of } \\
\text { genes }\end{array}$ \\
\hline \multirow[t]{3}{*}{ LUG-4 } & lymphoma & 8 & 42,XY,del(3)(qter),der(17) t(3;17) (qter;pter) & $(17 \mathrm{p}+) / \mathrm{RB} 1$ \\
\hline & & 22 & “ & \\
\hline & & 128 & 84,XX,YY,idemx2 & \\
\hline \multirow[t]{2}{*}{ MAL-1 } & healthy & 10 & $42, \mathrm{XX}$ & M5-der(11)/c-Ki-ras \\
\hline & & 166 & 42,XX,M1-M8 & M7-der(16)/TP53 \\
\hline \multirow[t]{2}{*}{ MB-20 } & healthy & 36 & $42, \mathrm{XY}, / 45, \mathrm{XY},+2,+8,+15 /$ & $(+8) / \mathrm{c}-\mathrm{myc}$ \\
\hline & & 76 & $45, \mathrm{XY},+2,8,+\operatorname{der}(15) \mathrm{t}(5 ; 15) \mathrm{q} 21 ;$ pter $)$ & \\
\hline
\end{tabular}


In tumour line LUG-4, cells had the initially pseudodiploid karyotype. Chromosomal marker $17 p+$ specific for LUG-4 was also found in all subclones E1-1, E5-1, and E9-1. By passage 128, LUG-4 became completely tetraploid.

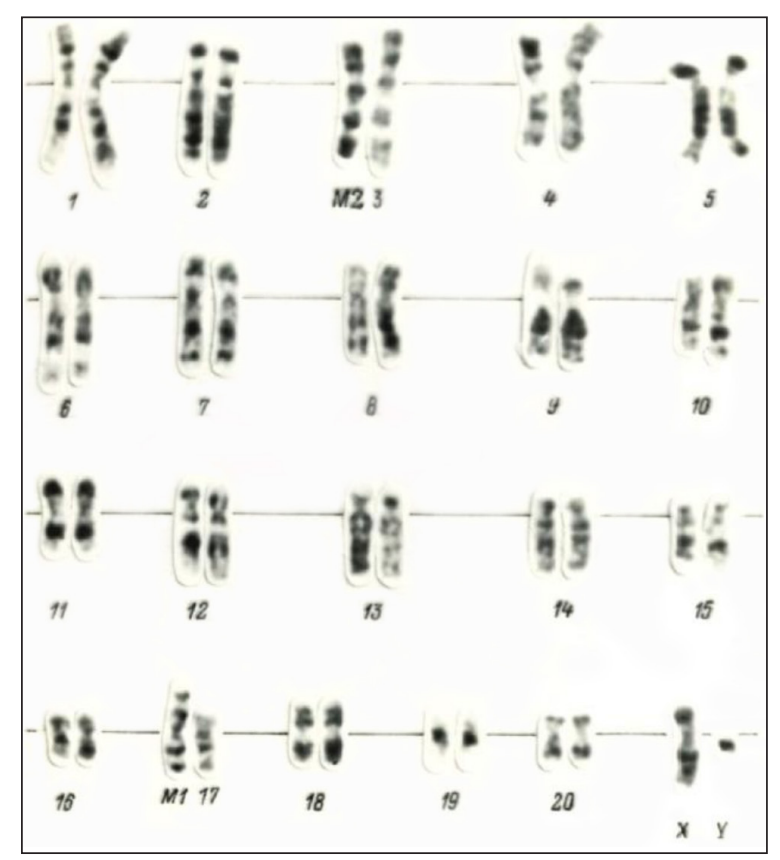

Fig. 1. Karyotype of parental cell line LUG-4 and its subclones (E1-1, E9-1, E5-1), 42, XY, del(3), der(17) $\mathrm{t}(3 ; 17)$ (qter;pter) (G staining)

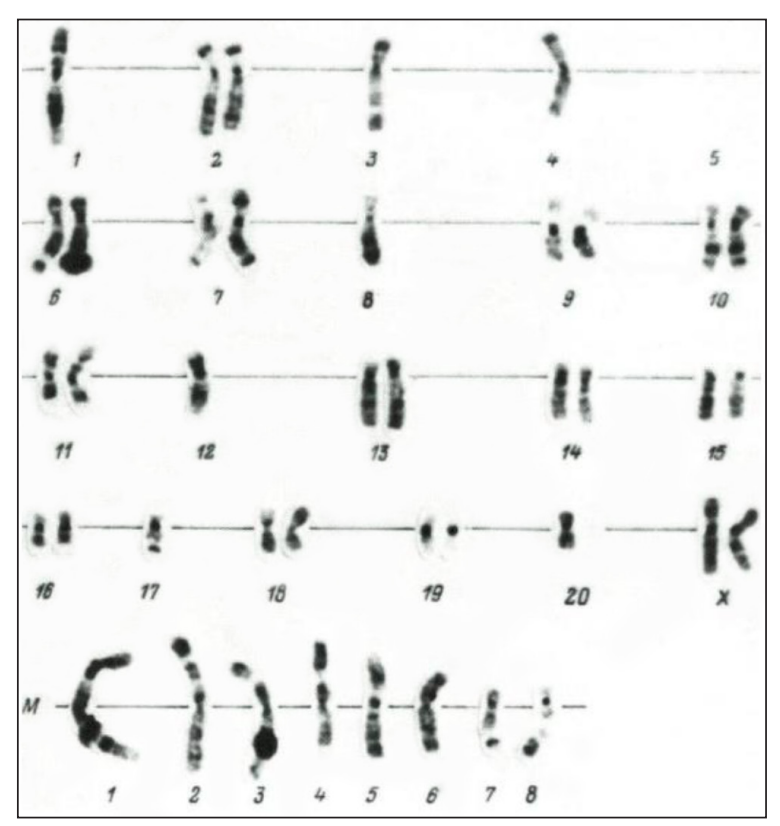

Fig. 2. Karyotype of B-cell line MAL-1, 42, XX, eight marker chromosomes (G staining)

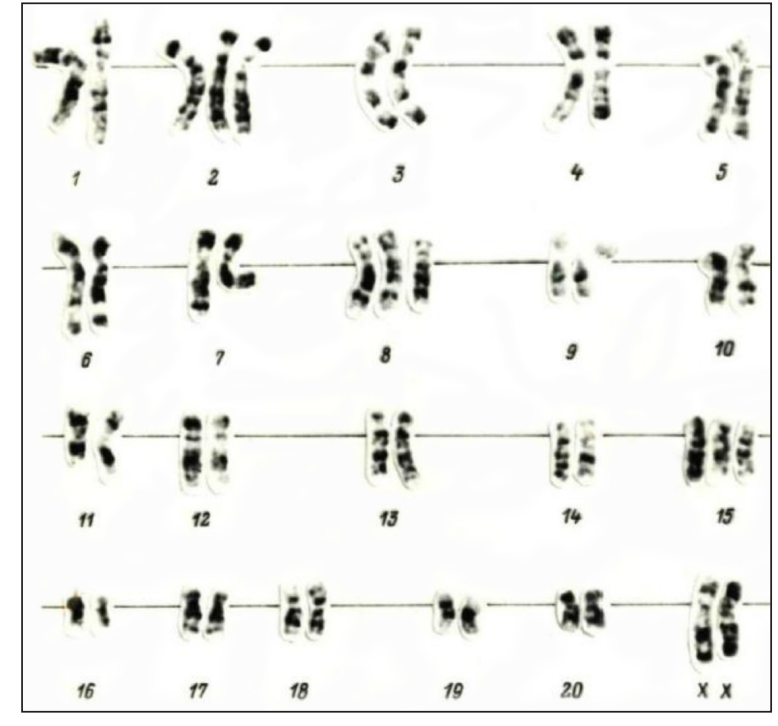

Fig. 3. Karyotype of the B-cell line MB-20, 45, XY, trisomy of 2, 8, and 15 chromosomes (G staining)

Analysed at different stages of cultivation, cell line MAL-1 was unstable. Karyotypical instability increased during the cultivation process. At initial stages (passage 10), we found cells with a normal karyotype 42, XX. By passage 26, some cells with chromosomal rearrangements appeared, and by passage 166, all cells with an initially normal karyotype had a pseudodiploid karyotype with eight marker chromosomes, in particular, der(11) and $\operatorname{der}(16)$.

In MB-20 cell line, three clones of cells with a different modal number of chromosomes were revealed: one clone with normal karyotype and two clones with abnormal karyotypes. In the process of cultivation, the same clones remained in the line, their ratio slightly changed.

Results of our search through the Ensembl database showed that in baboons and macaques, tumour suppressor gene RB1 is located in chromosome 17 , oncogene $c$-Ki-ras (KRAS) - in chromosome 11, tumour suppressor gene TP53 - in chromosome 16, and the proto-oncogene $c-m y c$ - in chromosome 8 (Tables 2-5) (Chromosome 17. Olive baboon, 2019; Chromosome 11, Chromosome 16, Chromosome 8 Macaque, 2019). All results are presented in Table 6. 
Table 2. Localisation of RB1 oncogene in human and rhesus macaque chromosomes

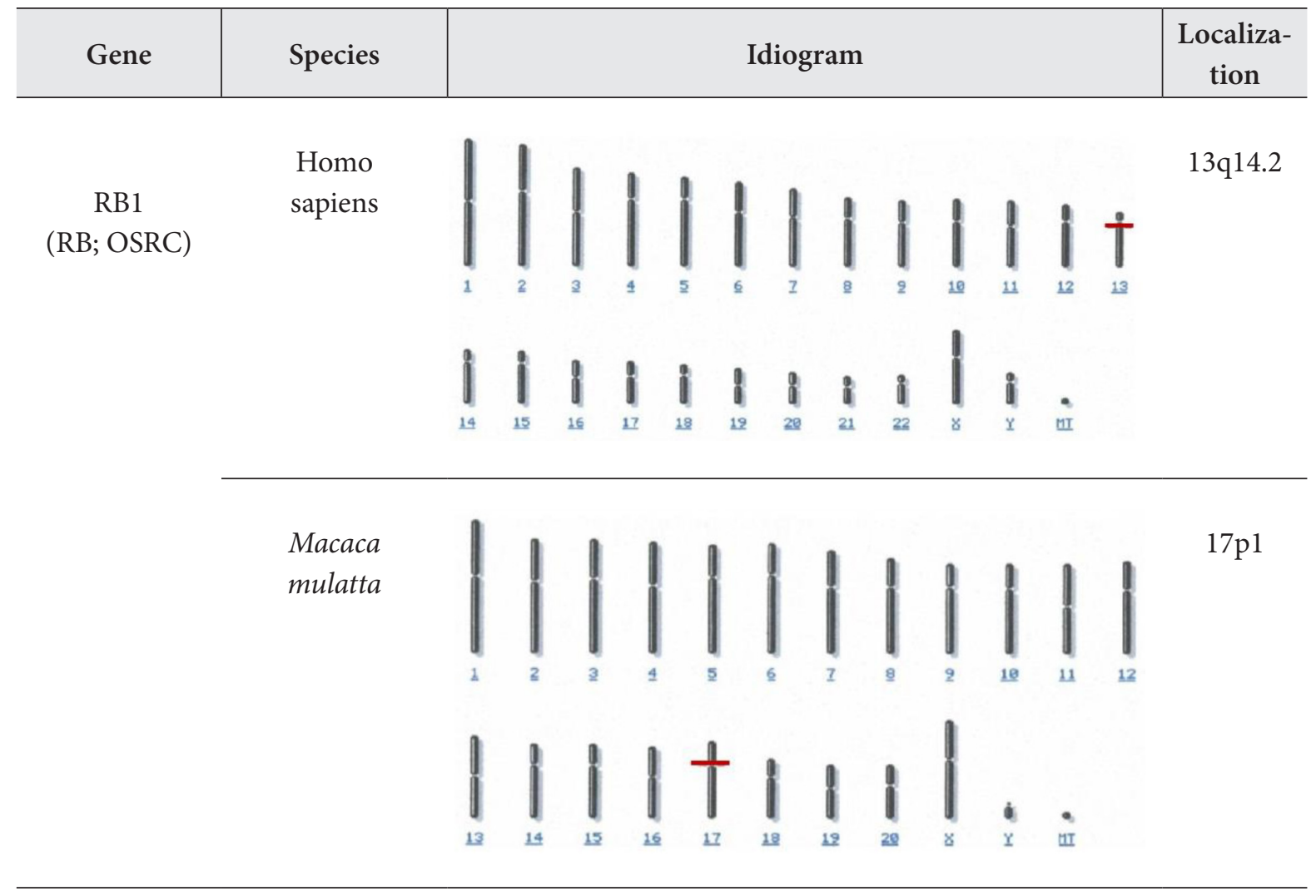

Table 3. Localisation of $\boldsymbol{c}$-Ki-ras oncogene in human and rhesus macaque chromosomes

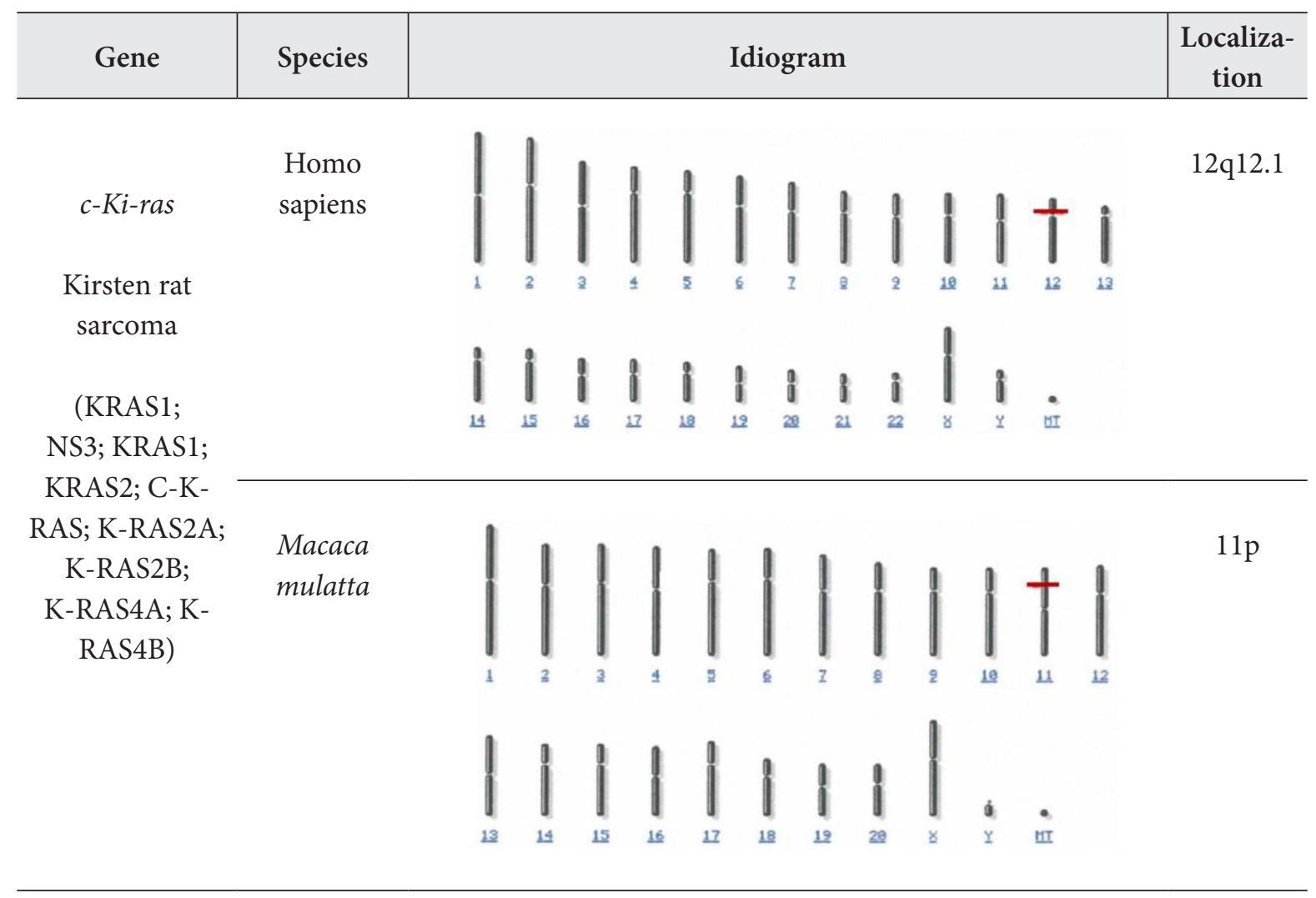


Table 4. Localisation of tumour suppressor gene TP53 in human and rhesus macaque chromosomes

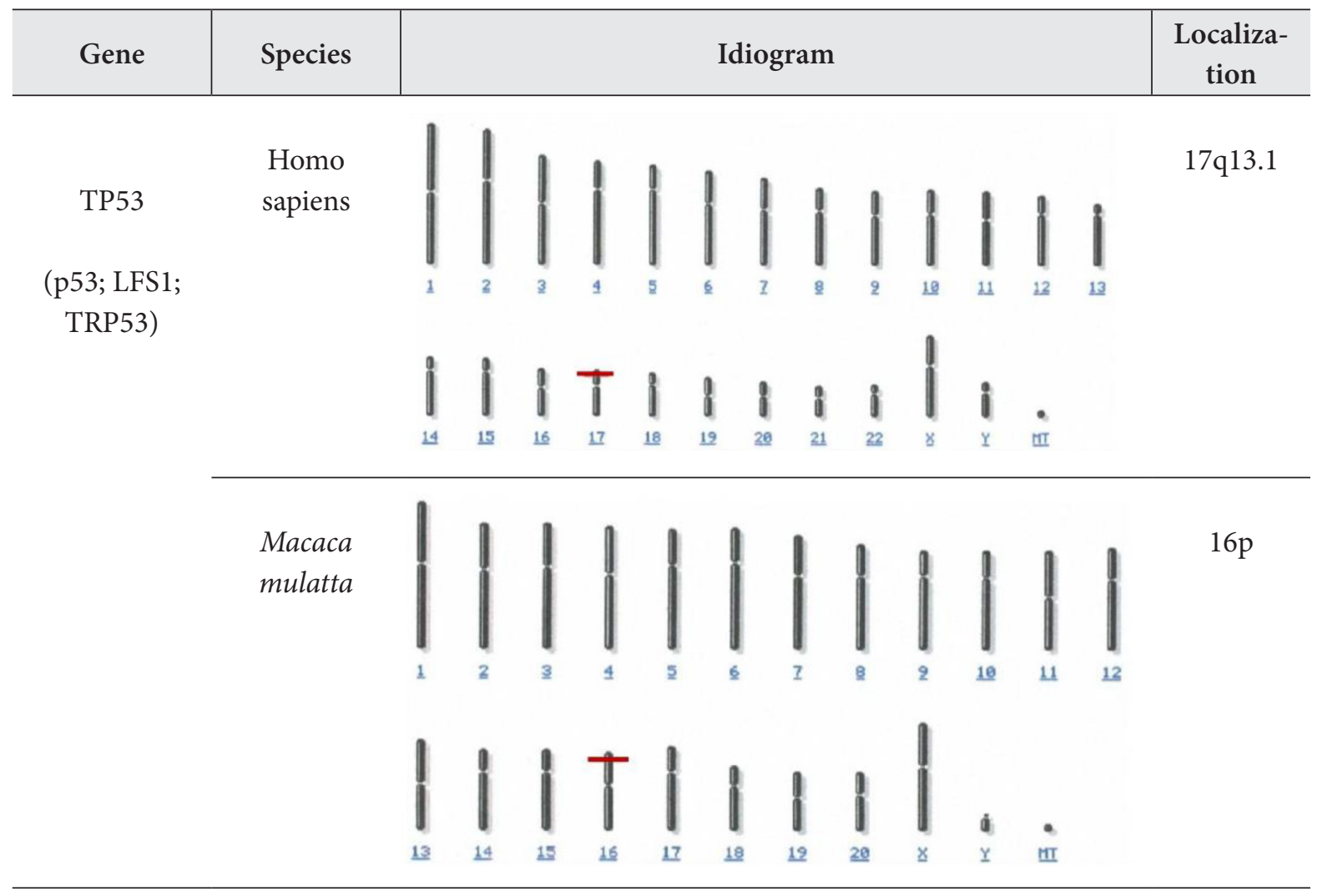

Table 5. Localisation of $\boldsymbol{c}$-myc oncogene in human and rhesus macaque chromosomes

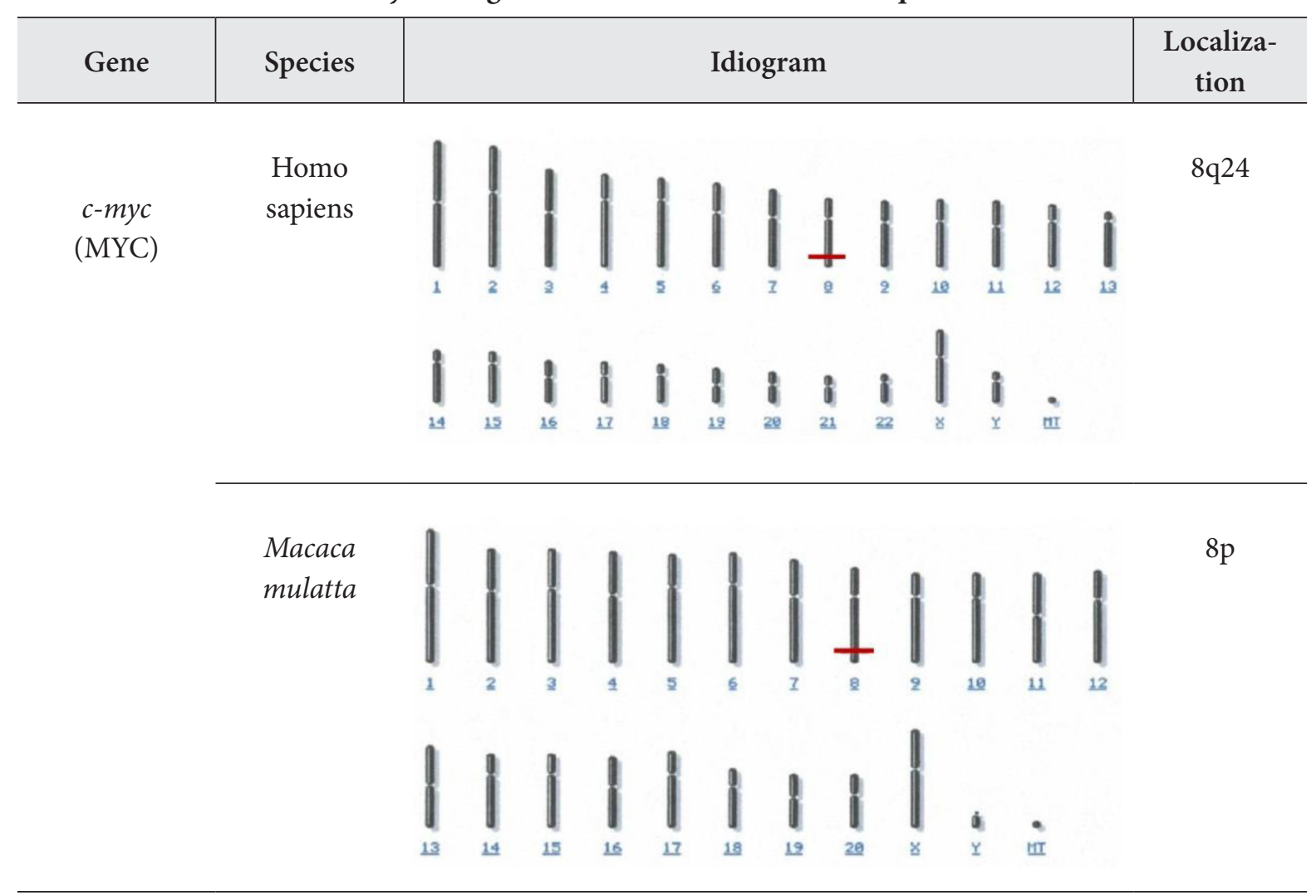


Table 6. Localisation of important genes in human and monkey chromosomes

\begin{tabular}{|c|c|c|c|c|}
\hline \multirow{2}{*}{ Gene } & \multirow{2}{*}{ Gene product function } & \multicolumn{3}{|c|}{ Location (chromosome №) } \\
\hline & & Human & Macaque & Baboon \\
\hline$c d c a 7$ & cell division control & 2 & 12 & 12 \\
\hline$p d c d 1$ & apoptosis regulation & 2 & 12 & 12 \\
\hline erb B4 & receptor tyrosine kinase 4 & 2 & 12 & 12 \\
\hline$b c l 6$ & oncogenic & 3 & 2 & 2 \\
\hline met & oncogenic & 7 & 3 & 3 \\
\hline ST7 & tumour suppressor & 7 & 3 & 3 \\
\hline$c-m y c$ & oncogenic & 8 & 8 & 8 \\
\hline $\operatorname{pax} 5$ & differentiation control & 9 & 15 & 15 \\
\hline ccnd1 & cyclin D1 & 11 & 14 & 14 \\
\hline$c$-Ki-ras & oncogenic & 12 & 11 & 11 \\
\hline$R B 1$ & tumour suppressor & 13 & 17 & 17 \\
\hline $\operatorname{IgH}$ & immunoglobulin heavy chain & 14 & 7 & 7 \\
\hline nupr1 & transcriptional regulator & 16 & 20 & 20 \\
\hline TP53 & tumour suppressor & 17 & 16 & 16 \\
\hline$c$-erb B2 & oncogenic & 17 & 16 & 16 \\
\hline$b c l 2$ & tumour suppressor & 18 & 18 & 18 \\
\hline
\end{tabular}

\section{DISCUSSION}

We investigated the established B-cell suspension lines of baboons and macaques. From the hamadryas baboon ill with lymphoma, the cell line LUG-4 and its subclones E1-1, E5-1 and E9-1 were obtained. We found that the translocation $\mathrm{t}(3 ; 17)$ was a structural chromosomal rearrangement specific for this line and was presented in the original lymphoma tissue cells in vivo. Subclones E1-1, E5-1 and E9-1 had the same karyotype.

It is well known that in the majority of cases the malignant growth is caused by activation of oncogenes and deactivation of tumour suppressor genes. Discussing our results from this point of view, we see that in the rhesus macaque and in the olive baboon, tumour suppressor gene $R B 1$ is located in the chromosome 17 .

According to early data in the literature, monkey chromosomes 3 and 17 were considered to be homologous to the corresponding human chromosomes (Gibbs et al., 2007). In human chromosome 17, tumour suppressor gene TP53 and proto-oncogenes c-erb B2 (re- ceptor tyrosine kinase 2), c-erb $A 1$, and c-erb $A 2$ are located, but our search in the Ensemble database showed that in monkeys these genes are situated in chromosome 16, except c-erb A2, which was found in chromosome 2 .

Considering chromosome 3 , the human chromosome contains proto-oncogene bcl6, which is overexpressed in $40 \%$ of diffuse large B-cell lymphoma (Rosenthal, Younes, 2017). According to the newest data, this gene was found in chromosome 2 in monkeys (Ensembl, 2019). Instead, the monkey chromosome 3 contains the proto-oncogene met (receptor tyrosine kinase) and the gene suppressor of tumorigenicity 7 (ST7), which is not studied but its role in oncogenesis is proved.

Summing up the foregoing, it can be concluded that the most probable cause of malignization in monkeys due to translocation $t(3 ; 17)$ is the inactivation of tumour suppressor genes $R B 1$ and $S T 7$, and activation of the proto-oncogene met.

From cells of clinically healthy bear macaques (Macaca arctoides) seropositive against EBV-like virus, lines MAL- 1 and MB-20 were obtained after stimulation with phytohemagglutinin. 
In line MAL- 1 we found the following marker chromosomes: $1,3,4,5,11,16,17$. The appearance of marker chromosomes was accompanied by loss of normal chromosomes 8, 12, 20.

Both in humans and monkeys, chromosome 8 contains the proto-oncogene $c-m y c$.

Chromosome 12 of rhesus macaque includes gene $p d c d 1$ (programmed cell death 1) coding the surface membrane protein of the immunoglobulin superfamily. The product of this gene, protein Pdcd1, takes part in B-cell differentiation (Mishra, Verma, 2018).

Also, in chromosome 12, the gene erbb4(receptor tyrosine kinase 4) is located. Mitogenesis and differentiation are among various mechanisms activated by this receptor. According to the literature, mutations in erb-b4 are associated with malignancies (Longo et al., 2019). The second gene in this chromosome, $c d c a 7$ encodes the protein associated with cell division. Protein Cdca7 is important for tumour growth because it mediates the effect of Myc in cancer cells (Jiménez et al., 2018).

In chromosome 20, gene nupr1 encodes the transcriptional regulator nuclear protein 1. It was shown that this protein takes part in transcriptional misregulation in cancer and is also involved in the regulation of cell cycle, apoptosis, autophagy, and DNA repair responses (Emma et al., 2016).

Proto-oncogene $c$-Ki-ras is located in monkey chromosome 11, and tumour suppressor gene TP53 is located in chromosome 16.

In cell line MAL-1, the appearance of marker chromosomes and the loss of normal chromosomes is a bad sign for normal karyotype. Favourable conditions for malignization are established, taking into account the above-listed genes located in these chromosomes and their importance for growth and apoptosis.

Cell line MB-20 is the only line which contained poplyploid clones (45 chromosomes) with a trisomy of chromosomes 2, 8 and 15 . Chromosome 8 contains proto-oncogene $c$ myc. Monkey chromosome 15 includes gene pax 5 coding the protein important for B-cell differentiation (Okuyama et al., 2019). Apparently, the found trisomy of chromosomes 8 and
15 damages the regulatory gene mechanisms and leads to immortalization.

In conclusion, we may underline that detected chromosomal aberrations cause functional changes in DNA and result in abnormalities in cell differentiation and proliferation.

\section{CONCLUSIONS}

1. Translocations, inversions and partial deletions are the most characteristic types of chromosomal rearrangements not only in leukaemia and lymphomas, but also during long-term cultivation of haemopoetic primate tissues.

2. Structural aberrations in established primate cell lines affect several chromosomal loci and cause the proto-oncogene activation - the central event in the tumour clone occurrence - and deactivation of tumour suppressor genes.

3. The numerical change of chromosomes (trisomy) leads to an increase in oncogenic products, and as a consequence, a damage of regulatory functions associated with cell proliferation.

4. Our data contribute to the understanding of cell features in culture.

Received 18 June 2019

Accepted 25 October 2019

\section{References}

1. Aberg E, Saccoccia F, Grabherr M, Ore W, Jemth P, Hultqvist G. Evolution of the p53MDM2 pathway. BMC Evol Biol. 2017; 17: 177-89.

2. Araviashvili DE, Agrba VZ, Timanovskaia VV, Tsvileneva NN, Mamaeva SE. The cytogenetic characteristics of B-lymphoid lines from Papio hamadryas baboons and Macaca arctoides brown macaques. Cytology (Tsitologiia). 1994; 36(7): 701-7. Russian.

3. Bende R, Smit L, van Noesel C. Molecular pathways in follicular lymphoma. Leukemia. 2007; 21: 18-29. 
4. Di Fiore R, D’Anneo A, Tesoriere G, Vento R. RB1 in cancer: different mechanisms of RB1 inactivation and alterations of $\mathrm{pRb}$ pathway in tumorigenesis. J Cell Physiol. 2013; 228(8): 1676-87.

5. Draganov AB, Yang $X$, Anifowose A, De La Cruz L, Dai C, Ni N, Chen W, De Los Santos Z, Gu L, Zhou M, Wang B. Upregulation of p53 through induction of MDM2 degradation: Anthraquinone analogs. Bioorg Med Chem. 2019; 27(17): 3860-5.

6. Emma MR, Iovanna JL, Bachvarov D, Puleio R, Loria GR, Augello G, Candido S, Libra M, Gulino A, Cancila V, McCubrey JA, Montalto G, Cervello M. NUPR1, a new target in liver cancer: implication in controlling cell growth, migration, invasion and sorafenib resistance. Cell Death Dis. 2016; 7(6): 2269-73.

7. Ensembl Release 96. 2019. Available fromhttp://www.ensembl.org/index.html

8. Gorfe AA, Cho KJ. Approaches to inhibiting oncogenic K-Ras. Small GTPases. 2019; 22: $1-10$.

9. Gibbs RA, Rogers J, Katze MG, Bumgarner R. Evolutionary and biomedical insights from the rhesus macaque genome. Science. 2007; 316(5822): 222-34.

10. Gurtsevitch VE, Demina EA, Senyuta NB, Botezatu IV, Smirnova KV, Dushen'kina TE, Maksimovich DM, Paramonova UV, Monin IS, Lichtenshtein AV. Epstein-Barr virus in patients with classical Hodgkin's lymphoma clinical oncohematology. 2018; 11(2): 160-6.

11. Jiménez PR, Martín-Cortázar C, Kourani O, Chiodo Y, Cordoba R, Domínguez-Franjo MP, Redondo JM, Iglesias T, Campanero MR. CDCA7 is a critical mediator of lymphomagenesis that selectively regulates anchorageindependent growth. Haematologica. 2018; 103(10): 1669-78.

12. Jung D, Giallourakis C, Mostoslavsky R, Alt F. Mechanism and control of $\mathrm{V}(\mathrm{D}) \mathrm{J}$ recombination at the immunoglobulin heavy chain locus. Annu Rev Immunol. 2006; 24: 541-70.
13. Levy D, Bertoldi E, Ruiz J, Pereira J, Bydlowski S. Presence of $t(14 ; 18)$ translocation in healthy individuals varies according to ethnic background in the Brazilian population. Braz J Med Biol Res. 2017; 50(7): 6172-6.

14. Longo JF, Brosius SN, Black L, Worley SH, Wilson RC, Roth KA, Carroll SL. ErbB4 promotes malignant peripheral nerve sheath tumor pathogenesis via Ras-independent mechanisms. Cell Commun Signal. 2019; 17(1): 74-93.

15. Mishra A, Verma M. Epigenetic and Genetic Regulation of PDCD1 Gene in Cancer Immunology. Methods Mol Biol. 2018; 1856: $247-54$.

16. Mugnaini EN, Ghosh N. Lymphoma. Prim Care. 2016; 43(4): 661-75.

17. Okuyama K, Strid T, Kuruvilla J, Somasundaram R, Cristobal S, Smith E, Prasad M, Fioretos T, Lilljebjörn H, Soneji S, Lang S, Ungerbäck J, Sigvardsson M. PAX5 is part of a functional transcription factor network targeted in lymphoid leukemia. PLoS Genet. 2019; 15(8): 1-22.

18. Peveling-Oberhag J, Arcaini L, Hansmann ML, Zeuzem S. Hepatitis C-associated B-cell non-Hodgkin lymphomas. Epidemiology, molecular signature and clinical management. J Hepatol. 2013; 59: 169-77.

19. Rosenthal A, Younes A. High grade B-cell lymphoma with rearrangements of MYC and BCL2 and/or BCL6: Double hit and triple hit lymphomas and double expressing lymphoma. Blood Rev. 2017; 31(2): 37-42.

20. Shannon-Lowe C, Rickinson AB, Bell AI. Epstein-Barr virus-associated lymphomas. Philos Trans R SocLond B Biol Sci. 2017; 372(1732): 1-15.

21. Uxa S, Bernhart SH, Mages CFS, Fischer M, Kohler R, Hoffmann S, Stadler PF, Engeland K, Müller GA. DREAM and RB cooperate to induce gene repression and cell-cycle arrest in response to p53 activation. Nucleic Acids Res. 2019; 47(17): 9087-103. 
22. Wienberg J, Stanyon R, Jauch A, and Cremer T. Homologies in human and Macaca fuscata chromosomes revealed by in situ suppression hybridization with human chromosome specific DNA libraries. Chromosoma. 1992; 101: 264-79.

23. Chromosome 17. Olive baboon. Ensembl database. Available from http://www.ensembl.org/ Papio_anubis/Location/View? $\mathrm{db}=$ core;g=ENS PANG00000007572;r=17:26734896-26902440

24. Chromosome 11. Macaque. Ensembl database.Available from http://www.ensembl.org/ Macaca_mulatta/Location/View? $\mathrm{db}=$ core; $\mathrm{r}=$ $11: 26138145-26182199$; g= ENSMM UG00000015381.

25. Chromosome 16. Macaque. Ensembl database. Available from http://www.ensembl.org/ Macaca_mulatta/Location/View? $\mathrm{db}=$ core; $\mathrm{r}=$ $16: 7650581-7660717$; g= EN S M M UG00000008639

26. Chromosome 8. Macaque. Ensembl database. Available from http://www.ensembl.org/ Macaca_mulatta/Location/View? $\mathrm{db}=$ core; $\mathrm{r}=8$ : 127089827 - 127097896 ; $\mathrm{g}=\mathrm{ENSMM}$ UG00000014601

\section{Daredzhan Araviashvili, Olga Chzhu, Igor Marinich, Irina Danilova}

\section{NEATSITIKTINĖS STRUKTŪRINĖS CHRO- MOSOMOS ABERACIJOS BEŽDŽIONIŲ B LIMFOCITŲ LĄSTELIŲ LINIJOSE}

Primatų limfocitų ląstelių linijos, išskirtos iš navikų ir beždžionių, kurioms nustatytas EBV, buvo pavyzdinè sistema tiriant genetinių veiksnių ir chromosomų anomalijų ịtaką piktybinių navikų susidarymui. Mūsų darbo tikslas - ištirti chromosomų regionų sritis ir genus, susijusius su chromosomų aberacijomis, sukeliančiomis šių linijų piktybinių navikų susidarymą. Citogenetiné analizė buvo atlikta skirtingais auginimo etapais in vitro. Onkogenų ir naviką slopinančių genų, esančių ant aberantinių chromosomų, nustatymui buvo naudojami rezus makakų genų žemèlapio bei didelio žmogaus ir beždžionių kariotipų panašumo duomenys. Mes nustatėme, kad linijoje, gautoje iš babuino limfomos audinio, naviko slopintuvo RB1 geno inaktyvacija 17 chromosomoje po chromosomų persitvarkymo yra viena iš labiausiai tikètinų piktybinių navikų susidarymo in vivo priežasčių. Chromosomų aberacijos c-Ki-ras onkogeno regione ir naviką slopinančio TP53 geno srityje keičia proliferacinę būklę ir diferenciaciją nustatytose ląstelių linijose, gautose iš sveikų, bet EBV seropozityvių primatų. Kita šių linijų piktybinių navikų susidarymo priežastis yra c-myc onkogeno ekspresijos padidejimas, kuri sukelia 8 chromosomos trisomija ten, kur yra $c-m y c$. Nustatytos struktūrinès tirtų primatų ląstelių linijų, turinčių ịtakos keliems chromosomų lokusams, aberacijos: 1) sukeliančios protoonkogeno aktyvaciją - pagrindinę naviko klono susidarymo priežastị, 2) „išjungiančios“ naviką slopinančius genus. Dèl pasikeitusio chromosomų skaičiaus padidejja onkogeninių darinių kiekis ir pažeidžiamos reguliacinès funkcijos, susijusios su ląstelių dauginimusi.

Raktažodžiai: citogenetinè analizè, kariotipas, chromosomų persitvarkymas, genų lokalizacija 